\title{
Montana Flume Flow Corrections under Submerged Flow
}

\author{
Ryan P. Willeitner, M.S., A.M.ASCE ${ }^{1}$; Steven L. Barfuss, P.E., M.ASCE'; and \\ Michael C. Johnson, P.E., M.ASCE ${ }^{3}$
}

\begin{abstract}
A Montana flume is a Parshall flume without a diverging downstream section and is used to measure open channel flow. Under free-flow conditions, the Parshall flume and the Montana flume have the same calibration characteristics, but under submerge flows, their calibrations significantly differ. Tests were conducted at the Utah Water Research Laboratory on an acrylic 15.2-cm (6-in.) Montana flume to determine the effects of submergence on the flow readings. This type of investigation has not been previously analyzed. It was found that a standard Parshall flume rating curve overpredicted flow rates in the submerged Montana flume, up to 48\%. Parshall submergence corrections were applied to the submerged Montana flume, and flow rates were underpredicted by up to $19 \%$. This study has developed submerged flow rate correction factors specifically for a Montana flume, and the paper also demonstrates how to apply the corrections. DOI: 10.1061/(ASCE) IR.1943-4774.0000434. (C) 2012 American Society of Civil Engineers.
\end{abstract}

CE Database subject headings: Montana; Flumes; Open channel flow; Flow measurement; Free flow; Submerged flow.

Author keywords: Montana; Flume; Submerged; Correction; Open channel; Flow measurement; Parshall flume; Free flow.

\section{Introduction}

Montana flumes are open channel measurement structures and are often mistaken for Parshall flumes, which are more common. As seen in Fig. 1, a Montana flume is truncated and does not include any geometry downstream of the throat, whereas a Parshall flume continues downstream of the throat. When properly installed and under regular operating conditions, both flumes have the same free-flow rating curves because critical depth occurs at the same location for both flumes in the throat. The flow rate is controlled at critical depth as the flow conditions pass from subcritical to supercritical flow.

According to Skogerboe et al. (1967), free flow and submerged flow are the two most significant flow regimes for a Parshall flume. A flume is operating under free-flow conditions when the conditions downstream of the flume do not affect the water depth on the upstream side of the flume. Submergence occurs when downstream conditions affect the flow rate through the structure and is measured as a ratio of the downstream head, $H_{b}$, to the upstream head, $H_{a}$. Both head measurements are referenced to the elevation of the converging section floor (see Fig. 1) and are usually expressed as a percentage (Skogerboe et al. 1967). Experimental data does not indicate a unique degree of submergence at which the transition from free-flow to submerged flow occurs. This can be attributed to the

${ }^{1}$ Graduate Research Assistant, Utah State Univ., 215 South State St., Suite 1000, Salt Lake City, UT 84010 (corresponding author). E-mail: rwilleit@ch2m.com

${ }^{2}$ Research Associate Professor, Utah State Univ., Dept. of Civil Engineering, UT Water Research Laboratory, 8200 Old Main Hill, Logan, UT 84322. E-mail: steve.barfuss@usu.edu

${ }^{3}$ Research Associate Professor, Utah State Univ., Dept. of Civil Engineering, UT Water Research Laboratory, 8200 Old Main Hill, Logan, UT 84322. E-mail: michael.johnson@usu.edu

Note. This manuscript was submitted on February 23, 2011; approved on November 15, 2011; published online on June 15, 2012. Discussion period open until December 1, 2012; separate discussions must be submitted for individual papers. This technical note is part of the Journal of Irrigation and Drainage Engineering, Vol. 138, No. 7, July 1, 2012. CASCE, ISSN 0733-9437/2012/7-685-689/\$25.00. instability of the flow at critical depth and how the structure behaves hydraulically.

The most significant design parameter for a Montana flume is that it operates under free-flow conditions [U. S. Dept. of the Interior, Bureau of Reclamation (USBR) 2001]. During a recent field study (Heiner 2009) within the state of Utah, Montana flumes were often found operating under submerged conditions. The Water Measurement Manual (USBR 2001) makes the following comment on Montana flumes under these conditions:

\begin{abstract}
"Care must be taken to construct Parshall flumes according to the structural dimensions given. This factor becomes more important as size gets smaller. The portion of the flume downstream from the end of the converging section need not be constructed if the flume has been set for free-flow where it is not expected to operate above the submergence limit. This truncated version of the Parshall flume is sometimes referred to as the Montana flume. Submergence corrections or discharge cannot be determined for Montana flumes or other modified Parshall flumes because they do not include the part of the full Parshall flume where the submergence head, $H_{b}$, was measured during calibration. (p. 8-24)"
\end{abstract}

After reviewing the geometry of a Parshall flume, the downstream head, $H_{b}$, is actually in the throat of the flume. Likewise, the Montana flume incorporates the $H_{b}$ at this location (see Fig. 1). Parshall flumes have a method for measuring submergence and making corrections to accurately measure the flow. Montana flumes have what is required to measure submergence but do not have any correction data available even though submergence was noted in field use. This study reports the necessary flow rate corrections for a $15.2-\mathrm{cm}$ (6-in.) Montana flume when it is operating under a submerged condition.

\section{Experimental Procedure}

At the Utah Water Research Laboratory in Logan, Utah a 15.2-cm (6-in.) Montana flume was constructed utilizing the original Parshall (1936) design specifications but without a diverging 


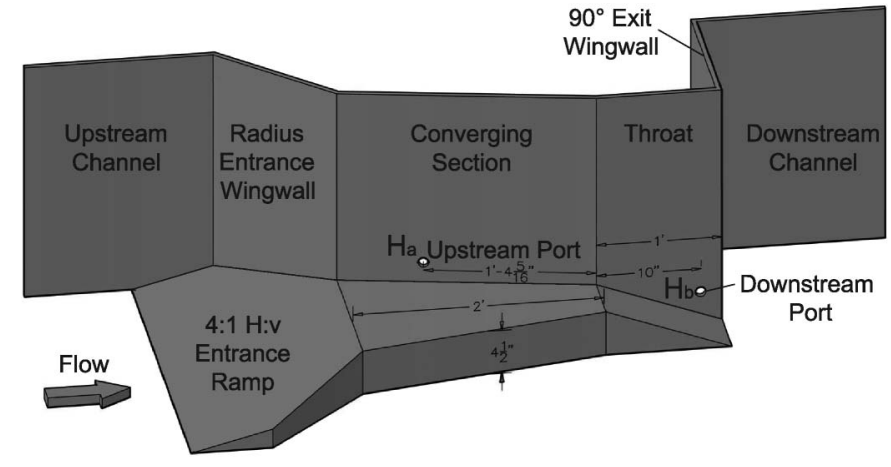

Fig. 1. Montana flume (15.2 cm throat width) with near wall removed; flow from left to right

downstream section. The laboratory Montana flume had $45^{\circ}$ entrance wingwalls upstream of the converging section and $90^{\circ}$ exit wingwalls downstream of the throat, as was commonly noted during recent field studies (Heiner 2009) in the State of Utah (see Fig. 1). According to design specifications, a 4:1 horizontal to vertical ramp extended upstream of the flume to funnel the flow through the flume. The Montana flume was secured inside a 81.4-cm (3-ft) wide channel, which allowed for proper approach flow conditions upstream and the ability to regulate the downstream depth. The flume was leveled by using surveying equipment, and all design specifications were within $\pm 0.8 \mathrm{~mm}$ (1/32 in.) of design as specified in the Water Measurement Manual (USBR 2001). Laboratory flow rates were measured by using a recently calibrated orifice plate, which was accurate to within $\pm 0.5 \%$. A standard orifice equation and pressure differential across the orifice plate were used to calculate the flow rate during each laboratory test.

Various head measurement devices were installed for the laboratory tests. A stilling well was installed at the $H_{a}$ and $H_{b}$ locations on both sides of the flume. A scale with tick marks every $0.25 \mathrm{~cm}$ ( 0.1 in.) was attached to each stilling well by using the flume's converging section floor as an elevation datum. Additional depth scales were installed on one side of the flume wall to act as staff gauges so that the water surface elevations at $H_{a}$ and $H_{b}$ could be directly measured.

The design flow range for a 15.2-cm Parshall flume is from $0.0014 \mathrm{~m}^{3} / \mathrm{s}(0.05 \mathrm{cfs})$ to $0.110 \mathrm{~m}^{3} / \mathrm{s}(3.9 \mathrm{cfs})$. Because of physical constraints of the laboratory channel, 12 evenly spaced flow rates were tested from $0.0071 \mathrm{~m}^{3} / \mathrm{s}(0.25 \mathrm{cfs})$ to $0.085 \mathrm{~m}^{3} / \mathrm{s}$ $(3.0 \mathrm{cfs})$. For each flow rate, the upstream head $\left(H_{a}\right)$ and downstream head $\left(H_{b}\right)$ measurements were collected for submergence $\left(H_{b} / H_{a}\right)$ values up to $90 \%$. For each flow rate, the submergence was increased by raising the tailwater. Each flow rate and tailwater setting was allowed to stabilize for approximately $4 \mathrm{~min}$ before readings were taken, although most flows were stable within $2 \mathrm{~min}$. The set flow rate during testing did not deviate more than $0.001 \mathrm{~m}^{3} / \mathrm{s}(0.05 \mathrm{cfs})$ for the entire range of submergences.

\section{Results}

\section{Standard Parshall Rating Table}

Laboratory results revealed that correction factors were necessary for the measured test data to correctly match the calculated flow through a submerged Montana flume. Standard Parshall equations are customarily used to calculate free-flow through a Montana flume, as shown in Eq. (1) (USBR 2001)

$$
Q=C\left(H_{a}\right)^{n}
$$

In a 15.2-cm flume, $Q=$ free-flow rate in cfs; $C=$ constant 2.06; and $n=$ exponent 1.58 . The combination of $n$ and $C$ makes Eq. (1) dimensionally consistent. If the free-flow equation [Eq. (1)] is improperly applied to a submerged Montana flume, inaccuracies can be as high as $48 \%$ when submergence reaches $90 \%$. Fig. 2 shows the true flow through the flume as reference points and the Parshall free-flow equation applied to the data. When applying the standard Parshall equation to submerged conditions in a Parshall flume, inaccuracies were also noticed by Parshall (1936) during his original testing. Modifications were made to the standard rating table when a Parshall flume was submerged.

\section{Parshall Submergence Correction}

To adjust for submerged flow conditions in a Parshall flume, Parshall (1936) developed a correction equation for when downstream conditions affected the upstream head. When a 6-in Parshall flume is operating above $55 \%$ submergence, the correction equation is as follows:

$$
Q_{S}=\frac{C_{1}\left(H_{a}-H_{b}\right)^{n_{1}}}{\left[C_{2}\left(\ln \frac{H_{b}}{H_{a}}+C_{3}\right)\right]^{n_{2}}}
$$

where the constants $C_{1}, C_{2}$ and $C_{3}=1.66,-0.434$, and 0.0101 , respectively; $n_{1}$ and $n_{2}=1.58$ and 1.080 , respectively; and $H_{a}$ and $H_{b}$ are the upstream and downstream head measurements as previously discussed. When Eq. (2) is applied to the data collected in this study for a Montana flume, the results deviated by as much as $19 \%$. This is shown in Fig. 2 as the Submerged Parshall equation. This indicates that a submerged Parshall equation correction cannot accurately be applied to a Montana flume. Because of the diverging geometry, the flow through a Parshall flume will push the hydraulic jump further away from the downstream stilling well $H_{b}$. In a Montana flume, the hydraulic jump is closer to where critical depth occurs in the throat. This causes an increase of water depth in the downstream stilling well and increases the submergence value.

\section{Transitional Submergence}

The point when downstream conditions begin to affect the upstream head readings is considered the transitional submergence (Skogerboe et al. 1967). For a 15.2-cm (6-in.) Parshall flume, transitional submergence is reached approximately when $H_{b} / H_{a}$ is greater than $55 \%$. The exact value of transitional submergence is difficult to determine and is based on calculations of trendlines

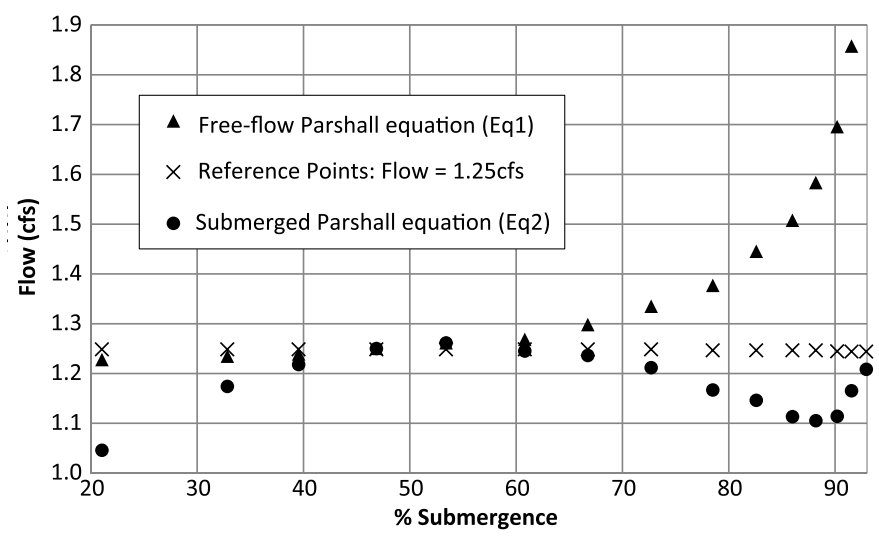

Fig. 2. Standard Parshall equations applied to a 15.2-cm (6-in.) Montana flume 
representing the data. The transitional submergence for the $15.2-\mathrm{cm}$ (6-in.) Montana flume tested in the laboratory over all flow ranges was found to be an average of $51 \%$. This indicates that a Montana flume has a lower transitional submergence value than a Parshall flume.

\section{Testing Observations}

As observed by Wright and Taheri (1990), when a 30.5-cm (1-ft) Parshall flume was tested under submergence, low discharges had more uncertainty. Wright and Taheri (1990) noticed some discharges to be as far off as $25 \%$ from the true value. At smaller flows, small deviations in upstream head resulted in large changes in flow calculations. Another testing difficulty noted by Skogerboe et al. (1967) was around the unstable transition submergence zone. Flows in this region are unsteady, and both upstream and downstream stilling well readings could oscillate by as much as $\pm 1.02 \mathrm{~cm}(0.4 \mathrm{in}$.) on alternating sides of the flume. This occurs because the hydraulic jump enters the throat in which the stilling well readings are taken, and hydrostatic conditions do not apply. During this study, this anomaly only occurred at a submergence of $51 \pm 3 \%$ depending on the flow rate. In this small transition, range conditions would be steady for approximately $12 \mathrm{~s}$, then, the tail water would wash out and change the downstream head measurements. After 6-10 s the steady state condition would establish itself again.

Heiner et al. (2011) and Blaisdell (1994) recognized surface waves in a Parshall flume with $45^{\circ}$ wingwalls at high flows. In the $15.2 \mathrm{~cm}$ Montana flume with $45^{\circ}$ wingwalls, surface waves also formed after the contraction and reached a maximum of $1.52 \mathrm{~cm}$ (0.6 in.). Velocities were minimal and the streamlines recovered to their original free surface elevation before the upstream stilling well port or staff gauge. The upstream staff gauge was within $0.13 \mathrm{~cm}$ (0.05 in.) of the stilling wells, and the right and left stilling wells were equal.

During the low submergence tests, the downstream staff gauge reading did not match the stilling well values. At low submergence, the staff gauge reading was higher than the stilling well, but as submergence increased, the stilling well reading became larger. Conditions at the downstream stilling well were unsteady, and regular hydrostatic pressure did not apply.

It was also determined that the upstream heads $\left(H_{a}\right)$ for freeflow conditions on the Montana flume were slightly different than the standard Parshall $H_{a}$ values for freeflow. Small deviations from the standard Parshall rating have been noted by Abt et al. (1992) during Parshall testing. The Montana flume $H_{a}$ values alone underpredicted the flow rate by as much as $2.3 \%$ compared to the Parshall rating. These deviations were within Parshall's (1936) design accuracy of 3-5\% and are considered acceptable.

\section{Testing Summary}

The data given in Figs. 3 and 4 was obtained during the laboratory testing and only applies to a $15.2-\mathrm{cm}$ Montana flume. Each actual flow rate (given in the legend) was measured using a calibrated orifice plate in the supply pipeline. Flow rates on the $Y$-axis were calculated using Eq. (1). Eq. (1) is traditionally used for the freeflow equation and only uses the upstream head. If only the upstream head is considered, then, as submergence increases, it appears that the flow increases, even though it was kept at a constant rate. The upstream head measurement typically begins to increase without an increase in flow rate above $50 \%$ submergence. This flow regime is known as the transitional submergence zone, in which downstream conditions affect the upstream head. The lower flow rates have a higher transitional submergence. The lower flow rates also have more scatter, and the higher flows show smooth curves.

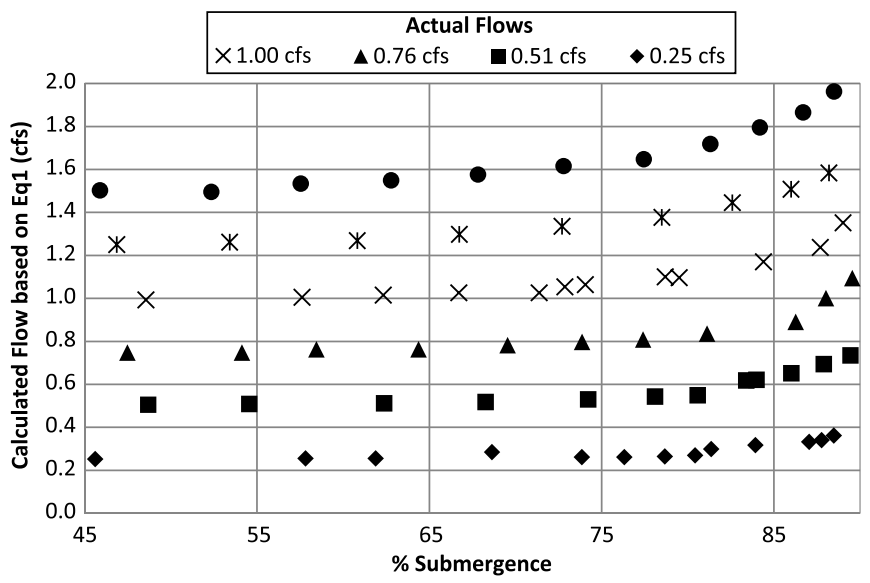

Fig. 3. High flow rates for a 15.2-cm (6-in.) Montana flume

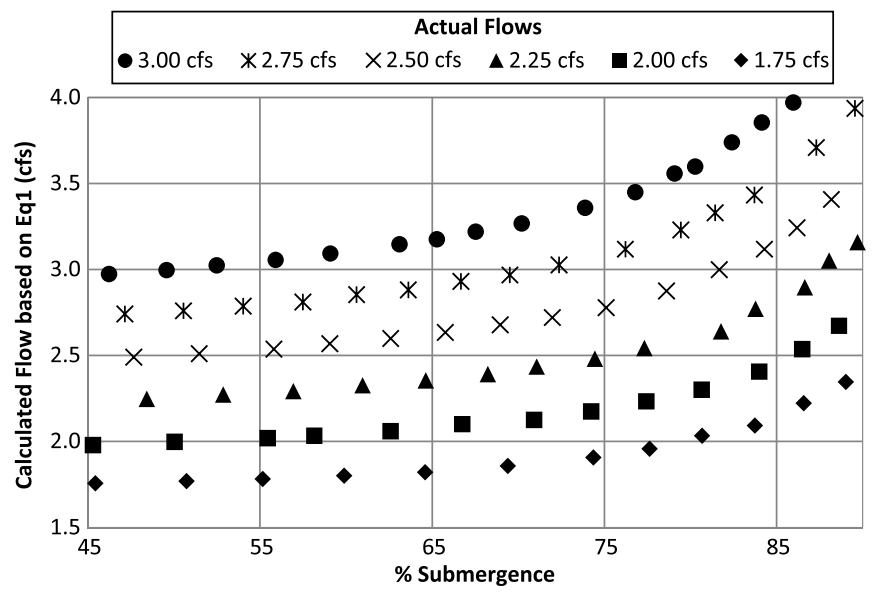

Fig. 4. Low flow rates for a 15.2-cm (6-in.) Montana flume

As is common in Parshall flumes, submergence values for the Montana flume are only shown up to $90 \%$ because minor depth increases are difficult to detect beyond this point but have a large influence on the flow rate calculations. Similar submergence curves to those shown in Figs. 3 and 4 have been noted for cutthroat flumes under similar conditions (Torres and Merkley 2008).

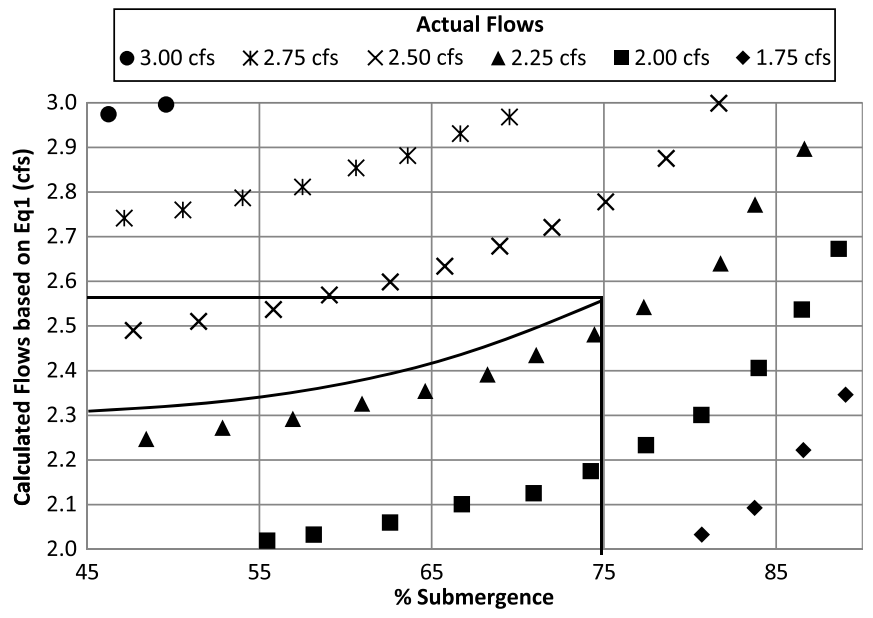

Fig. 5. Graphical correction for laboratory data 
Table 1. Correction Factors Based on Laboratory Data

\begin{tabular}{lllllllllllll}
\hline Flow rate (cfs) & 0.25 & 0.51 & 0.76 & 1.00 & 1.25 & 1.51 & 1.75 & 2.00 & 2.25 & 2.49 & 2.75 & 3.00 \\
\hline \% Submerged & & & & & & & & & & \\
45 & 1.002 & 1.012 & 1.011 & 1.014 & 0.991 & 0.998 & 0.992 & 1.003 & 1.000 & 0.999 & 1.000 & 1.005 \\
48 & 1.000 & 1.010 & 1.009 & 1.011 & 0.985 & 0.997 & 0.984 & 0.993 & 0.991 & 0.989 & 0.991 & 0.998 \\
51 & 0.998 & 1.007 & 1.007 & 1.007 & 0.983 & 0.996 & 0.980 & 0.987 & 0.984 & 0.982 & 0.985 & 0.991 \\
54 & 0.996 & 1.004 & 1.004 & 1.002 & 0.982 & 0.995 & 0.978 & 0.983 & 0.980 & 0.978 & 0.980 & 0.984 \\
57 & 0.993 & 1.000 & 1.000 & 0.997 & 0.982 & 0.994 & 0.977 & 0.981 & 0.977 & 0.974 & 0.975 & 0.977 \\
60 & 0.991 & 0.996 & 0.995 & 0.992 & 0.982 & 0.991 & 0.975 & 0.978 & 0.973 & 0.970 & 0.969 & 0.969 \\
63 & 0.987 & 0.990 & 0.990 & 0.986 & 0.980 & 0.985 & 0.972 & 0.974 & 0.967 & 0.964 & 0.961 & 0.958 \\
66 & 0.983 & 0.984 & 0.984 & 0.980 & 0.974 & 0.977 & 0.966 & 0.967 & 0.958 & 0.955 & 0.950 & 0.944 \\
69 & 0.979 & 0.977 & 0.978 & 0.973 & 0.965 & 0.965 & 0.955 & 0.956 & 0.946 & 0.941 & 0.935 & 0.926 \\
72 & 0.973 & 0.970 & 0.970 & 0.962 & 0.952 & 0.948 & 0.939 & 0.940 & 0.928 & 0.923 & 0.915 & 0.905 \\
75 & 0.966 & 0.960 & 0.962 & 0.949 & 0.932 & 0.927 & 0.918 & 0.918 & 0.905 & 0.899 & 0.890 & 0.880 \\
78 & 0.941 & 0.937 & 0.950 & 0.933 & 0.907 & 0.902 & 0.891 & 0.890 & 0.877 & 0.869 & 0.860 & 0.851 \\
81 & 0.888 & 0.888 & 0.910 & 0.896 & 0.876 & 0.872 & 0.858 & 0.856 & 0.843 & 0.834 & 0.825 & 0.818 \\
84 & 0.811 & 0.826 & 0.851 & 0.842 & 0.839 & 0.839 & 0.820 & 0.816 & 0.804 & 0.793 & 0.786 & 0.782 \\
87 & 0.744 & 0.754 & 0.776 & 0.777 & 0.798 & 0.802 & 0.777 & 0.772 & 0.761 & 0.749 & 0.743 & 0.743 \\
90 & 0.697 & 0.677 & 0.692 & 0.705 & 0.753 & 0.762 & 0.731 & 0.725 & 0.715 & 0.703 & 0.699 & 0.703 \\
\hline
\end{tabular}

\section{Uncertainties}

Some potential errors have been noted by other authors when dealing with flumes. As seen by Wright and Taheri (1990), when a 30.5-cm (1-ft) Parshall flume was tested under submergence, low discharges had more uncertainty. During laboratory testing, repeat runs needed to be performed for the $15.2-\mathrm{cm}$ Montana at low flows because this uncertainty also existed. Small flows were also more difficult to measure because minor deviations in upstream head could result in larger changes in flow calculations. Another difficulty was the transition submergence zone as seen by Skogerboe et al. (1967). Flows in this region are unsteady, and the stilling well readings could oscillate by as much as $\pm 0.76 \mathrm{~cm}$ (0.3 in.).

Minor flow changes were detected on the basis of an average flow measurement from the orifice meter. These flows were adjusted if they ever exceeded more than $0.001 \mathrm{~m}^{3} / \mathrm{s}(0.05 \mathrm{cfs})$ for any given flow rate. Some error may also exist in reading the upstream and downstream heads because of surface tension of the water or not viewing the scale at eye level.

\section{Application}

Adjustment factors for submergence were developed and are applicable for submergence levels greater than $45 \%$. To determine the flow rate of a submerged 15.2-cm (6-in.) Montana flume, the upstream $\left(H_{a}\right)$ and downstream $\left(H_{b}\right)$ head measurements are required. The free-flow equation [Eq. (1)] is first used to find the uncorrected flow rate, then, the submergence is calculated $\left(H_{a} / H_{b}\right)$. Figs. 3 and 4 can then be used to trace these two values to an intersecting point. An arc can then be drawn that follows parallel to the upper and lower binding data points (see Fig. 5). When the $Y$-axis of the graph is intersected, the corrected flow rate can be determined.

As an example of correcting the flow rate graphically, Fig. 5 is used with $H_{a}$ and $H_{b}$ values of $35.1 \mathrm{~cm}(1.15 \mathrm{ft})$ and $26.2 \mathrm{~cm}$ $(0.36 \mathrm{ft})$, respectively. Using Eq. (1), the flow is calculated as $0.073 \mathrm{~m}^{3} / \mathrm{s}$ (2.57 cfs). The submergence is calculated by dividing $H_{b}$ by $H_{a}$, giving a value of $75 \%$. By finding where these two values intersect on Figs. 3 or 4 and following the data points to the Y-axis on the graph, an adjusted flow rate of $0.065 \mathrm{~m}^{3} / \mathrm{s}$ $(2.31 \mathrm{cfs})$ is obtained.

A second approach is possible through interpolating correction factors. Third order polynomials were used to approximate flows from $0.007-0.085 \mathrm{~m}^{3} / \mathrm{s}(0.25-3.00 \mathrm{cfs})$ and had a correlation coefficient value greater than 0.96 . Table 1 can be used to interpolate between flows by using the given submergence value. The polynomial approximations are only valid for submergence from $45-90 \%$. Because of physical limitations of the channel in which tests were performed, values for $0.085 \mathrm{~m}^{3} / \mathrm{s}(3.00 \mathrm{cfs})$ could only be obtain for up to $87 \%$ submergence. Flow rates are obtained using Eq. (1) and are then multiplied by the correction factor, $\alpha$, in the table. If the same values of $H_{a}$ and $H_{b}$ are used as in the graphical example ( 1.15 and 0.85 , respectively), the uncorrected flow rate would be $0.073 \mathrm{~m}^{3} / \mathrm{s}(2.57 \mathrm{cfs})$ with a submergence of $75 \%$. By linearly interpolating the uncorrected flow rate at $75 \%$ submergence, the correction coefficient, $\alpha$, is 0.896 . The actual flow rate is obtained by multiplying the flow rate and the correction factor, providing a result of $0.065 \mathrm{~m}^{3} / \mathrm{s}$ $(2.30 \mathrm{cfs})$ The graphical and interpolation methods yield similar results.

\section{Conclusion}

The results from this research confirm that the $15.2-\mathrm{cm}$ (6-in.) Parshall flume rating table may be used for a 15.2-cm free-flow Montana flume. However, the Parshall rating table used for submergence corrections cannot be used if the 3-5\% accuracy parameters specified by Parshall (1936) are to be achieved. This research also determined that the transitional submergence level is less for a $15.2-\mathrm{cm}$ Montana flume (51\%) than for a 15.2-cm Parshall flume $(55 \%)$. This means that the downstream depth does not need to be as high in a Montana flume to affect the upstream head measurements. Correction coefficients and methods of correcting flow measurements are provided for a $15.2-\mathrm{cm}$ Montana flume with $45^{\circ}$ entrance wing walls and $90^{\circ}$ exit wing wall. A graphical and a coefficient method are demonstrated that yield similar results. The correction factors presented herein are only valid for a smooth 15.2-cm Montana flume with submergence of 45-90\%. The data presented in this document cannot be extended to other sizes of 
Montana flumes because they are not geometrically similar. Additional research was performed by the authors on submergence corrections for other sized Montana flumes using numerical computational fluid dynamics but are not presented here. As part of that study, nine Montana flume sizes were tested including a $0.152 \mathrm{~m}$ (6-in), $0.229 \mathrm{~m}$ (9-in), $0.305 \mathrm{~m}$ (1-ft), $0.457 \mathrm{~m}$ (1.5 ft), $0.610 \mathrm{~m}$ $(2 \mathrm{ft}), 0.914 \mathrm{~m}(3 \mathrm{ft}), 1.22 \mathrm{~m}(4 \mathrm{ft}), 1.83 \mathrm{~m}(6 \mathrm{ft})$ and $2.44 \mathrm{~m}(8 \mathrm{ft})$ with similar submergence curves.

\section{References}

Abt, S. R., Cook, C., Staker, K. J., and Johns, D. D. (1992). "Small Parshall flume rating correction." J. Hydraul. Eng., 118(5), 798-803.

Blaisdell, F. W. (1994). "Results of Parshall flumes tests." J. Irrig. Drain. Eng., 120(2), 278-291.

Heiner, B. J. (2009). "Parshall flume staff gauge location and entrance wingwall discharge calibration corrections." M.S. thesis, Utah State Univ., Logan, UT.
Heiner, B. J., Barfuss, S. L., and Johnson, M. C. (2011). "Flow rate sensitivity due to Parshall flume staff gauge location and entrance wing wall configuration.” J. Irrig. Drain. Eng., 137(2), 94-101.

Parshall, R. L. (1936). "The Parshall measuring flume." Bulletin No. 423, Agricultural Experiment Station, Colorado Agricultural College, Fort Collins, CO.

Skogerboe, G. V., Hyatt, M. L., England, J. D., and Johnson, J. L. (1967). "Design and calibration of submerged open channel flow measurement structures. Part 2: Parshall flumes." Rep. WG31-3, Utah Water Research Labratory, Utah State Univ., Logan, UT.

Torres, A. F., and Merkley, G. P. (2008). "Cutthroat measurement flume calibration for free and submerged flow using a single equation." J. Irrig. Drain. Eng., 134(4), 521-526.

U. S. Dept. of the Interior, Bureau of Reclamation (USBR). (2001). Water measurement manual, 3rd Ed., U.S. Government Printing Office, Washington, DC.

Wright, S. J., and Taheri, B. (1990). "Limitations to standard Parshall flume calibrations." Proc., National Conf. on Hydraulic Engineering, ASCE, Reston, VA, 915-920. 